\title{
Innovation and Sustainability
}

\author{
Dr. Mukadder GÜNERI
}

\begin{abstract}
When we look at the history of humanity, it is seen that mankind has been experiencing a process of change that has not lived to this day. This process we are in is called globalization. There are many opinions about the happiness and the unhappiness of mankind related to globalization. Globalization is on the verge of questioning what sustainability will bring when it is thought of in the long run. On this result, when we search for answers to questions about what you can sustain; when we look for answers to this question, what is sustainability? Innovation comes to the forefront, which is two dimensions, technical and organizational. Whether the individual the private or the public the conditions of innovation are reflected in education and training. In the process we are in today (the developments in economic, cultural and socio-economic relations between countries), it is evident that it is imperative to have education and training to respond to the sustainability of innovation conditions._All these principles make life, life style. That is, to acquire information, to produce information, to produce common values, to protect social and individual values in the common values produced, to adapt to the rapid development of technology, to increase quality of life in existing conditions, to produce added value in existing conditions and to maintain its sustainability. In this work, the relevance of innovation to sustainability has been examined in a classical way.
\end{abstract}

Keywords: Education, Innovation, Sustainability.

\section{Introduction}

1.1. In today's world, which is called globalization, rapid changes in the field of technology show the influence of every field, both inside and outside conditions. This interaction is felt in every aspect of life, including military, economic, administrative, cultural, political and social. When we look at the changes that result from this interaction, "sustainability" seems to be important. The driving force of sustainability is the fast-paced innovation in communication technology, which facilitates the flow of information in both internal and external contexts.

1.2. Education and teaching are at the forefront of innovations that can be sustained both internally and externally (sustainability, roughly speaking, to keep things started or initiated).

\section{General Table}

2.1. Technological innovations ----- $<>-.---\rightarrow$ Globalization. 2.1.1. Internal and external interaction---- $\rightarrow$ 2.1.1.1.Military, 2.1.1.2. Judicial, 2.1.1.3. Economic, 2.1.1.4. Administrative, 2.1.1.5. Cultural, 2.1.1.6. Social, 2.1.1.7. Politics.

2.1.2. Interaction(innovation) $-----\rightarrow$ 2.1.3. Sustainability $---\rightarrow$ 2.1.4. Education. 2.1.4.1. Basic Education(primary school$--\rightarrow$ Higher education), 2.1.4.2. Specialization, 2.1.4.3. Lafe long Learning.

\section{Result}

As can be seen from the above table, the interactions seen in all areas of life are seen as keywords of "innovation", "sustainability" and "education", that is, globalization, as individuals or as societies. Moreover, the "life-long learning" in today's world is clear that the day will grow more and more.

\section{Bibliography}

[1] .(2011). TÜRKÇE SÖZLÜK, Türk Dil Kurumu Yayını, Ankara.

[2] .Akyüz, Yahya. (,2008, 2015). Türk Eğitim Tarihi. 27.Baskı. Ankara. 
[3] .Anonim, Endurun Tarihi, Belediye Kütüphanesi K. 470. Muallim Cevdet Yazmaları, İstanbul.

[4] .Aslandağ,Soylu, B., Yanper, Yelken, T. ( 5-8 February 2013). A New and Dynamic Phenomenon for Higher Education: Life-Wide Learning, 5th World

[5] Conference on Education Studies, Roma.

[6] .Aytaç, K. (1972, 2009,). Avrupa Eğitim Tarihi, Antik Çağdan 19.Yüzyılın Sonlarına Kadar, Dil ve Tarih Coğrafya Fakültesi Yayını, Ankara.

[7] .Burke, P. (2004). Bilginin Toplumsal Tarihi, çev. Tuncay, M, Tarih Vakfı Yurt Yayını, İstanbul.

[8] .Coşkun, Y.D. (2009). “Üniversite Öğrencilerinin Yaşam Boyu Öğrenme Eğilimlerinin Bazı Değişken Açısından Incelenmesi, " Basıımamış Doktora Tezi, Hacettepe Üniversitesi, Sosyal Bilimler Enstitüsü, Ankara.

[9] .Güneri, Mukadder. (29 Nisan-1 Mayıs 2009/ 29 April- 1 Mayıs 2009). "Atasözü Ve Deyimlerin Eğitice Ve Öğretici Yönü”. Adlı Bildiri, Uluslar arası Karşılaştırmalı Edebiyat, Edebiyat ve Dil Eğitimi Kongresi," s. 325-332. Gazi Üniversitesi, Ankara.

[10] .Güneri, Mukadder. (31 Mayıs- 02 Haziran 2012). "Eğitim Ve Yaşam" Adlı Bildiri, Eğitimin Odağında Artvin Sempozyumu, s. Artvin Çoruh Üniversitesi, Artvin.

[11] .Güneş, F. (2000). Okuma -Yazma 7 Öğretimi ve Beyin Teknolojisi, Ocak Yayını, Ankara.

[12] .Geraskof, M. (1933). Talim ve Tedriste Kendi Kendine Faaliyet Prensibi, çev. Hasip Ahmet, Remzi Kitapevi Yayını, İstanbul.

[13] .http//www.gse.harvard.edu/ppe/program/prek-12/portfolio/lgl.

[14] .http/line.fi//en/article/researc/220132/three-perspectives-on-active-citizenship-in-lifelong-and life-wideeducation-research.

[15] ..Kaya, Y.K. (1989) İnsan Yetiştirme Düzenimize Yeni Bakış, Bilim Yayınları, Ankara.

[16] .Knapper, C., Cropley, A. (2000). Lifelong Learning in Higher Education, London.

[17] .Kurbanoğlu, S. (2010). "Bilgi Çağında Bilgi Okuryazarlığı, Bilgi Okuryazarlığından Yaşam Boyu Öğrenmeye," II. Ulusal Okul Kütüphanecileri Konferansı, İdeal Kültür Yayını, İstanbul.

[18] .Manguel, A. (2013). Okumanın Tarihi, çev. Eloğlu, F. Yapı Kredi Yayınları, İstanbul.

[19] .Milli Eğitim Bakanlığı. (2012- 2013). Milli Eğitim İstatistikleri Örgün Eğitim, Ankara.

[20] .Oktay, A. (1991). Yaşamın Sihirli Yılları “Okul Öncesi Dönem," Epsilon Yayıncılık, İstanbul.

[21] . Ş̧ş̧man, M. (2002). Eğitimde Mükemmellik Arayışları, Pegem Yayınları, Ankara.

[22] .Unat, F.R. (1964). Türkiye Eğitim Sistemin Gelişmesine Tarihi Bir Bakış, Milli Eğitim Basımevi, Ankara.

[23] .Weiner, B(1985) Human Motivation, New York. 